\title{
VARIATION IN THE ENERGY AND MACRONUTRIENT CONTENTS OF TEXTURE MODIFIED HOSPITAL DIETS
}

\section{VARIACIÓN EN LA ENERGÍA Y CONTENIDO DE MACRONUTRIENTES DE DIETAS HOSPITALARIAS CON TEXTURA MODIFICADA}

\author{
Patricia Viganó C. (1), Nilian Silva S. (1), Camila Cremonezi J. (1), \\ Guilherme Vannucchi P. (2), Marta Campanelli M. (3) \\ (1) Department of Internal Medicine, Medical School of Ribeirao Preto, \\ University of Sao Paulo. Sao Paulo, Brasil. \\ (2) Faculty of Nutrition, Federal University of Triangulo Mineiro. Brasil. \\ (3) Department of Pediatrics, Medical School of Ribeirao Preto, \\ University of Sao Paulo. Sao Paulo, Brasil.
}

\begin{abstract}
Objective: To compare the nutritional content of the main meals of a normal hospital diet with those of texture modified diets (soft, puréed and liquid). Methodoloogy: The ash, moisture, macronutrient and energy contents of the foods comprising the main meal of the hospital diets were determined. The values were calculated per capita for each food item comprising the diets and then added up in order to estimate the total amount of energy and macronutrients supplied by main meal. Results: Compared with the normal diet, the puréed and liquid diets presented higher moisture content as well as reduced content of energy (31.4\% and $39.9 \%$, respectively), protein (45.4\% and $79.8 \%$,respectively) and lipid (41\% and $76 \%$, respectively). Conclusion: Texture modified diets exhibit lower energy and macronutrient content, the main changes being detected for the liquid diet, which might imply an insufficient micronutrient supply.
\end{abstract}

Key words: hospital diets, nutritional composition, hospital undernutrition, texture modified diets, hospital food service.

Este trabajo fue recibido el 24 de Mayo de 2011 y aceptado para ser publicado el 10 de Noviembre de 2011.

\section{INTRODUCTION}

Undernutrition is generally related with increased morbidity and mortality as well as longer hospital stay and higher costs (1-3). It may arise from the clinical conditions of the patient and factors involved in the hospitalization process, which can culminate in inadequate nutritional intake.

Among the causes of insufficient energy and nutrient consumption are prescription errors, inadequate diet menus, unsatisfactory supply of nutrients in the oral diet, problems related to diet portioning and distribution, and low compliance with the hospital diet (2,4-7).

Except for the normal diet, all hospital diets differ from traditional ones in terms of texture and/or nutrient content. From a theoretical viewpoint, all hospital diets should meet the nutritional requirements of the assisted patient, independent of the modification. Because liquid diets are less likely to fulfill the nutritional needs of the patient, it has been suggested that they should be employed as a transition diet for a few days only, or that they should be combined with energy and nutritional supplementation (8).

Wright et al. (9) have analyzed the diets most commonly prescribed to elderly patients in two American hospitals (general; soft; hyposodic - 2g of salt/ meal, $1500 \mathrm{Kcal}, 60 \mathrm{~g}$ protein; full liquid; and clear liquid) and found that most of the modified diets were deficient in vitamins and minerals, although they supplied adequate energy, protein, and vitamin A levels.

Montoya et al. (10) have reported that in some cases the puréed diet does not present the same protein content as the normal diet. In fact, bromatological analysis revealed a variation in calorie and protein concentration of $64-78 \mathrm{kcal} / 100 \mathrm{~g}$ and $5.3-4.5 \mathrm{~g} / 100 \mathrm{~g}$, respectively. 
The loss of micronutrients during food preparation is extensively discussed in the literature (11-14). However, there are few studies comparing the macronutrient content of diets. According to Rodgers (15), food preparation does not lead to significant reduction in the amount of macronutrients.

Considering that (i) nutritional composition is a crucial factor during the design of balanced hospital diet plans, (ii) the main meals (lunch and dinner) correspond to the largest energy and nutrient intake within a 24hour period, and (iii) literature works on the nutritional composition of diets delivered to hospital patients are scarce $(16,17)$, the present work aimed to compare the nutritional composition of the main meals of the normal hospital diet with those of texture modified diets (soft, puréed, and liquid).

\section{MATERIALS AND METHODS}

A $200 \mathrm{~g}$ sample of each food item comprising the main meal of the normal, soft, puréed, and liquid hospital diets was collected on three random days in the portioning area of a Hospital Food and Nutrition Unit (HFNU).

Immediately after collection, the food samples (rice, beans, complements, meat, and desert, and soup, in the case of pureed and liquid diets) were weighed separately, homogenized in a blender, and dried in an oven equipped with air flow $\left(80^{\circ} \mathrm{C}\right)$ for a period of up to $72 \mathrm{~h}$. The dry samples were then triturated and used in further tests. Three five-gram aliquots of the homogenate were collected separately, for determination of the moisture content of the samples. Analysis of the ash and macronutrient contents of each preparation was accomplished in triplicate, according to the procedures described in Analytical Standards of the Adolfo Lutz Institute (18). The energy content was measured in a calorimetric pump, and the carbohydrate content was determined by calculating the difference between the total calorie content and the energy due to lipids and proteins.

Diet texture is generally modified by increasing the time during which the normal diet is cooked, which is commonly associated with elevated water content. In the case of the soft diet, rice is served in the same way as in the normal diet; beans are liquefied; complements, meat, and desert have a soft texture. As for the puréed diet, rice is overcooked; beans are liquefied; complements are served as purees; and meat is minced, liquefied, or shredded. Liquid diets consist of soup only, which is composed by meat, vegetables, and rice or spaghetti, accompanied by jelly, flan, or pudding.

The mean energy, macronutrient, moisture, and ash contents found in the triplicate analysis were converted to the quantities per capita established for each food item constituting the diets served by the HFNU. The per capita values were $150 \mathrm{~g}$ rice, $60 \mathrm{~g}$ beans, 60 to $80 \mathrm{~g}$ meat (depending on the preparation process), 60 to $80 \mathrm{~g}$ complement (depending on the preparation process), 80 to $100 \mathrm{~g}$ dessert (except for the liquid diet), $30 \mathrm{~g}$ salad, $200 \mathrm{~g}$ soup for the puréed diet, $400 \mathrm{~g}$ soup for the liquid diet, and $160 \mathrm{~g}$ dessert for the liquid diet.

To obtain the composition of the main meal of each diet, the values achieved for each food item included in a specific diet were added in terms of their respective per capita values. Next, the mean total energy and macronutrient content of each diet was calculated. Preparations common to the normal, soft, and puréed diets were also compared.

In order to determine the percent variation between the texture modified diets and the normal diet, the following formula was employed:

$\%$ variation $=[($ normal diet value - texture modified diet value) / normal diet value] x 100

\section{STATISTICAL ANALYSIS}

The mean energy, macronutrient, moisture, and ash contents of each texture modified diet were compared with those of the normal diet by non-parametric KruskalWallis test followed by Dunn's post. The significance level was set at $\mathrm{p}<0.05$. Data were analyzed using the Statistical Package for the Social Sciences ${ }^{\circledR}$ (SPSS) software, version 15.0.

\section{RESULTS}

Compared with the normal diet, the puréed and liquid diets were the ones with the most reduced energy (31.4\% and $39.9 \%$, respectively), protein $(45.4 \%$ and $79.8 \%$, repectively) and lipid (41.0 and $76.0 \%$, respectively) contents. However, statistical significance was observed in the case of the liquid diet only. Furthermore, the liquid diet presented significant variation in lipid and proteins contents, with the percent variation increasing with decreasing diet consistency (table 1).

The carbohydrate and ash contents of the various analyzed diets were not statistically different, compared with the normal diet. The moisture content of pureed diet was statistically different only from soft diet (table 1).

Separate analysis of the food items rice and beans showed that, compared with the normal diet, the rice served in the puréed diet provided lower energy content (63.2\% variation), as well as decreased macronutrient and ash values, while the moisture content was higher (49\%). Statistical differences between the pureed and normal diets were found only for the moisture content 
and between puréed and soft diets were found for the lipid content. The nutritional compositions of the rice portions served in the soft and normal diet were not statistically different (table 2).

With respect to the beans served in the analyzed diets, there was no significant variation in the nutritional composition of this food item in terms of energy, macronutrient, moisture and ash contents (table 3 ).

\section{DISCUSSION}

Texture modified hospital diets present reduced energy and macronutrient contents compared with the normal diet. The main alterations in protein and lipid contents (reductions larger than 75\%) can be detected in the case of the liquid diet.

As for the different methods of preparation of the food items rice and beans, the overcooked rice served

\section{TABLE 1}

Comparison between the normal diet and texture modified diets - mean calorie and macronutrient content and percent variation with respect to the main meal (lunch/dinner).

\begin{tabular}{lccccccc} 
& $\begin{array}{c}\text { Normal diet } \\
\text { Value }\end{array}$ & \multicolumn{2}{c}{ Soft diet } & \multicolumn{2}{c}{ Puréed diet } & \multicolumn{2}{c}{ Liquid diet } \\
& (SD) & $\begin{array}{c}\text { Value } \\
\text { (SD) }\end{array}$ & $\begin{array}{c}\% \\
\text { Variation }\end{array}$ & $\begin{array}{c}\text { Value } \\
\text { (SD) }\end{array}$ & $\begin{array}{c}\text { \% } \\
\text { Variation }\end{array}$ & $\begin{array}{c}\text { Value } \\
\text { (SD) }\end{array}$ & $\begin{array}{c}\% \\
\text { Variation }\end{array}$ \\
\hline Energy (kcal) & $628.8(47.3)$ & $554.7(77.0)$ & -11.7 & $431.2(91.9)$ & -31.4 & $377.4 *(81.1)$ & -39.9 \\
Proteins (g) & $38.2(5.5)$ & $27.3(11.3)$ & -28.6 & $20.8(7.4)$ & -45.4 & $7.7 *(5.8)$ & -79.8 \\
Lipids (g) & $15.0(1.4)$ & $12.1(1.3)$ & -19.1 & $8.8(1.2)$ & -41.0 & $3.6 *(3.8)$ & -76.0 \\
Carbohydrates (g) & $90.5(13.0)$ & $91.0(9.0)$ & +0.6 & $70.2(13.0)$ & -22.4 & $91.6(18.8)$ & +1.2 \\
Moisture (mL) & $335.6(9.3)$ & $299.1(12.1)$ & -10.8 & $539.3 * *(16.4)$ & +60.6 & $469.4(10.0)$ & +39.8 \\
Ash (g) & $5.3(0.3)$ & $5.2(0.7)$ & -2.4 & $6.6(0.8)$ & +23.1 & $2.8(2.9)$ & -47.4 \\
\hline $\begin{array}{l}\text { SD: Standard deviation. } \\
* \mathrm{p}<0.05 \text { in relation to the normal diet. }\end{array}$ \\
$* * \mathrm{p}<0,05$ in relation to the soft diet.
\end{tabular}

\section{TABLE 2}

Comparison between the rice served in the normal diet and in texture modified diets - Calorie and macronutrient content (per $100 \mathrm{~g}$ ) and percent variation.

\begin{tabular}{|c|c|c|c|c|c|}
\hline & \multirow{2}{*}{$\begin{array}{l}\text { Normal diet } \\
\text { Value } \\
\text { (SD) }\end{array}$} & \multicolumn{2}{|c|}{ Soft diet } & \multicolumn{2}{|c|}{ Puréed diet } \\
\hline & & $\begin{array}{l}\text { Value } \\
\text { (SD) }\end{array}$ & $\begin{array}{c}\% \\
\text { Variation }\end{array}$ & $\begin{array}{l}\text { Value } \\
\text { (SD) }\end{array}$ & $\begin{array}{c}\% \\
\text { Variation }\end{array}$ \\
\hline Energy (kcal) & $171.4(24.2)$ & $176.5(9)$ & +2.9 & $63.0(5)$ & -63.2 \\
\hline Proteins (g) & $2.4(0.5)$ & $2.4(0.6)$ & 0 & $1.7(0.5)$ & -30.0 \\
\hline Lipids (g) & $2(0.7)$ & $2.8(0.4)$ & +40.0 & $0.6 * *(0.0)$ & -70.0 \\
\hline Carbohydrates (g) & $35.8(7.2)$ & $35.3(2.6)$ & -1.4 & $12.5(0.7)$ & -65.1 \\
\hline Moisture (mL) & $56.9(0.3)$ & $59.1(1.4)$ & +3.8 & $84.8^{*}(0.8)$ & +49.0 \\
\hline $\operatorname{Ash}(\mathrm{g})$ & $1.3(0.1)$ & $1.2(0.3)$ & -7.7 & $0.5(0.2)$ & -61.6 \\
\hline
\end{tabular}


in the puréed diet exhibits higher moisture content, as expected. This is because a larger amount of water is utilized during its preparation, compared with the quantity employed in the preparation of the rice served in the normal diet.

Some studies evaluating cooking methods have demonstrated that heating can alter the moisture, protein, fat, and ash contents of food items, owing to the loss of nutrient and water $(19,20)$. Food processing may also influence the lipid content of diets, since part of the lipids can adhere to the walls of the container employed during food preparation $(21,22)$. In the case of hospital diets, additional modifications arising from the handling necessary for the desired texture to be achieved may also occur.

The relationship between ash content, cooking method, and other food components is not yet clear. Gall et al. (23) worked with fish fillet from different species and reported that heating resulted in lower moisture values, which consequently impacted on the ash content.

Using indirect analysis, Moreno et al. (24) identified inadequate energy (1339 Kcal), protein (58 g), and vitamin and mineral (vitamin C, iron, and calcium) contents in the case of the main meals of puréed diets designed for dysphagia patients.

The insufficient energy and macronutrient contents of the diets analyzed herein imply that there might also be deficient supply of vitamins and minerals, making the provision of nutrients according to the recommendations included in the Dietary Reference Intakes (DRIs) difficult. Therefore, texture modified diets should only be prescribed for individuals with clinical conditions that demand this dietary modification (25 - 27).

A study assessing the nutritional status and food intake of hospitalized patients detected that only $25 \%$ of the inpatients at nutritional risk had their energy and protein requirements met (28). Diet presentation, palatability of the preparations, and monotonous menus may further impair compliance of inpatients with the prescribed diet (25). Hamilton et al. (26) reported that hospitalized patients considered that approximately $1 / 3$ of texture modified diets were unattractive.

An investigation comparing the energy and nutrient intake of patients on three different types of diets revealed that those who received soft or puréed diet had lower energy, protein, calcium, and fiber intake compared with individuals following the normal diet (27).

Some authors hold the view that modified diets should provide the same energy and protein content as the normal diet (29). A variation of approximately $10 \%$ in macronutrient content might be acceptable for a healthy individual; however, this variation is considered an important nutritional risk factor in the case of inpatients requiring stricter control of nutrient intake (17).

Apart from the fact that the preparation of texture modified diets induces variation in nutritional composition, food composition tables do not furnish information about the contents of these modified foods. This impairs calculation of the real energy and nutrient contents of the diet and leads to errors in the estimation of nutritional values (30).

Taking into account the alterations in the nutritional

\section{TABLE 3}

\section{Comparison between the beans served in the normal diet and in texture modified diets - Calorie and macronutrient content (per $100 \mathrm{~g}$ ) and percent variation.}

\begin{tabular}{|c|c|c|c|c|c|}
\hline & \multirow{2}{*}{$\begin{array}{l}\text { Normal diet } \\
\text { Value } \\
\text { (SD) }\end{array}$} & \multicolumn{2}{|c|}{ Soft diet } & \multicolumn{2}{|c|}{ Puréed diet } \\
\hline & & $\begin{array}{l}\text { Value } \\
\text { (SD) }\end{array}$ & $\begin{array}{c}\% \\
\text { Variation }\end{array}$ & $\begin{array}{l}\text { Value } \\
\text { (SD) }\end{array}$ & $\begin{array}{c}\% \\
\text { Variation }\end{array}$ \\
\hline Energy (kcal) & $116.6(25.9)$ & $88.8(9.4)$ & -23.9 & $102.4(13.5)$ & -12.1 \\
\hline Proteins (g) & $5.4(0.1)$ & $5.0(0.8)$ & -7.5 & $5.7(4.7)$ & +5.5 \\
\hline Lipids (g) & $1.7(0.8)$ & $1.5(0.2)$ & -11.8 & $1.3(0.7)$ & -23.5 \\
\hline Carbohydrates (g) & $19.8(5.8)$ & $13.7(3.6)$ & -30.9 & $17.6(5.1)$ & -11.1 \\
\hline Moisture (mL) & $71.0(2.2)$ & $78.4(1.4)$ & +1.4 & $77.6(1.3)$ & +9.2 \\
\hline Ash (g) & $1.7(0.4)$ & $1.7(0.2)$ & -1.2 & $1.7(0.2)$ & 0 \\
\hline
\end{tabular}


contents of foods inherent to the preparation of texture modified diets, as described in the present work, approaches ensuring that the amount of energy and nutrients of the puréed and liquid diets delivered to hospitalized patients are similar to those of the normal diet should be undertaken.

Increased food portions might promote larger food intake, as demonstrated in many literature works $(31,32)$. However, the effect of larger food portions on the satiety of inpatients is not yet known. Indeed, some authors have shown that larger food portions might lead to the notion that a lot of energy will be consumed, culminating in lower food ingestion. According to Porrini et al. (33), feeding habits can be influenced not only by what individuals consume, but also by what individuals think they are consuming. Other studies have demonstrated that food portion has a larger effect than energy intake in the short-term $(34,35)$.

The provision of nutritional supplements in the form of snacks, prepared from natural food or industrialized products and served between the main meals, can help maximize intrahospital food ingestion. This strategy works by supplying the energy and the specific nutrient that is lacking in the patient's diet. Indeed, Johnson et al. (36) have reported a total offer of $1792 \mathrm{Kcal}$ by serving pureed food and snacks between meals.

Another possible approach would be increasing the energy density of hospital meals $(27,37,38)$ which could be achieved by adding ingredients containing a larger amount of calories within a small volume during food preparation. Examples of such ingredients are sugar, oil, milk cream, mayonnaise, and flour, among others.

\section{CONCLUSION}

It has been shown that decreased diet consistency incurs lower energy supply, which is a consequence of reduced macronutrient content. This result points to the need for revising the standardization of texture modified diets, so that recipes can be adapted and the nutritional density and volume of the preparations served in the main meals can be adjusted according to the nutritional requirements of the patient.

Some approaches can be suggested, in order to ensure nutritional adequacy of texture modified diets and diminish the nutritional risk of inpatients. Firstly, larger portions of food items could be served in the main meal, but care should be taken so as not to induce early satiety and inhibit complete ingestion of the meal. Secondly, food based on natural food items and/or industrialized products could be made available to patients between meals. Finally, the energy density of the preparations could be increased.

\section{RESUMEN}

Objetivo: Comparar la composición nutricional de las comidas principales en la dieta hospitalaria en general con los de las dietas modificadas para la consistencia (blanda, puré y líquida). Metodología: Se determinó el contenido de cenizas, humedad, nutrientes y energía de los alimentos de la comida principal de las dietas hospitalarias recogidas. Los valores fueron convertidos a cantidades per cápita establecidas para cada alimento de cada dieta y sumados con el fin de estimar el total ofrecido por la comida principal. Resultados: Las dietas líquida y puré tuvieron más humedad, reducción de 41 a $76.0 \%$ del contenido de grasas, reducción de 45.4 a $79.8 \%$ del contenido proteico y de 31.9 a $39.9 \%$ de la energía total. Conclusión: Las dietas de consistencia modificada presentaron una reducción en el contenido de energía y macronutrientes, encontrándose los principales cambios en la dieta líquida, lo que culminó en una probable disminución de la ingesta de micronutrientes.

Palabras clave: dieta hospitalaria, composición nutricional, desnutrición hospitalaria, dietas modificadas en consistencia, servicio de alimentación hospitalaria.

Dirigir la correspondencia a:

Profesora

Patricia Viganó Contri

Department of Internal Medicine

Medical School of Ribeirao Preto

University of Sao Paulo. Sao Paulo, Brasil.

R Campos Saller 398, Apto. 11

Centro Riberao Preto - SP

CEP: $14015-110$

E-mail: patriciacontri@yahoo.com.br

Acknowledgements: We thank the dietician Nancy Yukie Yamamoto Tanaka and Prof. Dr. Alceu Afonso Jordão Junior for institutional support.

\section{BIBLIOGRAFÍA}

1. Goiburu ME, Jure Goiburu MM, Bianco H, Díaz JR, Alderete F, Palacios MC, Cabral V, Escobar D, López R \& Waitzberg DL. The impact of malnutrition on morbidity, mortality and length of hospital stay in trauma patients. Nutr Hosp 2006; 21:604-10.

2. Leandro-Merhi VA, Diez Garcia RW, Mônaco DV \& Marques de Oliveira MR. Comparación del estado nutricional, consumo alimenticio y tiempo de hospitalización de pacientes de dos hospitales, uno público y otro privado. Nutr Hosp 2006; 21:32-7.

3. Elia M. Nutrition, hospital food and in-hospital mortality. Clin Nutr 2009; 28: 481-3. 
4. Diez Garcia RW. A dieta hospitalar na perspectiva dos sujeitos envaidos em sua produção e em seu planejamento. Rev Nutr 2006; 19:129-44.

5. Nonino-Borges CB, Rabito EI, Silva K, Ferraz CA, Chiarello PG, Santos JS \& Marchini JS. Desperdício de alimentos intra-hospitalar. Rev Nutr 2006; 19:349-56.

6. Dickinson A, Welch C, Ager L \& Costar A Hospital megltimes: action research for change? Proc Nutr Sod 2005; 64:269-75.

7. Prieto DB, Leandro-Merhi VA, Mônaco DV \& Lazarini ALG. Intervenção nutricional de rotina em pacientes de um hospital privado. Rev Bras Nutr Clin 2006; 21:181-7.

8. Martins C, Meyer LR, Savi F \& Morimoto IMI. Manual de Dietas hospitalares. Nutroclínica, $\mathrm{Cu}-$ ritiba, 2001

9. Wright JE, Willis GJ \& Edwards MS. Nutritional Content of Hospital Diets. JAMA 2004; 291:21942196.

10. Montoya MJ, Sanz A, Gutiérrez S, Gérez P, Gracia P, Caverna A \& Albero R. Dieta por turmix en pacientes hospitalizados como factor de riesgo de desnutrición. Nutr Hosp 2004; 19:8.

11. Santos MAT, Abreu CMP \& Carvalho VDD. Efeitos de diferentes tempos de cozimento nos teores de minerais em folhas de brócolis, couve-flor e couve (Brassica oleracea L.). Ciênc Agrotec 2003;

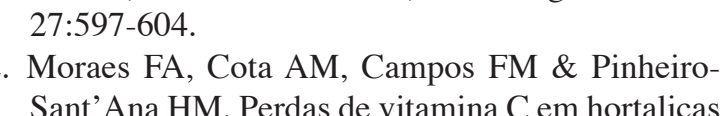
Sant'Ana HM Perdas de vitamina C em hortaliças durante o armazenamento, preparo e distribuição em restaurantes. Ciênc Saúde Colet 2010; 15:51-62.

13. Lesková E, Kubíková J, Kováciková E, Kosická M, Porubská J \& Holcíkova K. Vitamin losses: Retention during heat treatment and continual changes expressed by mathematical models. J Food Composition Anal 2006; 19:252-76.

14. Kumar S \& Aalbersberg B. Nutrient retention in foods after earth-oven cooking compared to other forms of domestic cooking. J Food Composition Anal 2006; 19:311-320.

15. Rodgers $\mathrm{S}$. The review of foodservice systems and associated research. Foodservice Res Internat 2004; 14:273-90.

16. Torres EAFS, Campos NC, Duarte M, Garbelotti ML, Philippi ST \& Rodrigues RSM. Composição centesimal e valor calórico de alimentos de origem animal. Ciênc Tecnol Aliment 2000; 20:145-50.

17. Ribeiro P, Morais TB, Colugnati FAB \& Sigulem DM. Tabelas de composição química de alimentos: análise comparativa com resultados laboratoriais.
Rev Saúde Públ 2003; 37:216-25.

18. Instituto Adolfo Lutz. Normas analíticas do Instituto Adolfo Lutz. Métodos químicos e físicos para análise de alimentos, São Paulo, 1985.

19. Vieira JO, Bressan MC, Faria PB, Ferreira MW, Ferrão SPB \& Souza XR. Efeito dos métodos de cocção na composição centesimal e colesterol do peito de frangos de diferentes linhagens. Ciênc Agrotec 2007; 31:164-70.

20. Gokoglu N, Yerlikaya P \& Cengiz E. Effects of cooking methods on the proximate composition and mineral contents of rainbow trout (Oncorhynchus mykiss). Food Chemistry 2004; 84:19-22.

21. Pedrosa LFC, Araújo MOD, Lima EB, Melo MSON \& Godeiro LMT. Análise química de preparações usuais em cardápios populares brasileiros. Rev Nutr 1994; 7:48-61.

22. Ribeiro MA, Stamford TLM, Eulálio C \& Filho J. Valor nutritivo de refeições coletivas: tabelas de composição de alimentos versus análises em laboratório. Rev Saúde Públ 1995; 29:120-6.

23. Gall KL, Otwell WS, Kobuguer JA \& Appledorf H. Effects of four cooking methods on the proximate, mineral and fatty acid composition of fish fillets. $\mathbf{J}$ Food Sci 1983; 48:1068-74.

24. Moreno C, García MJ, Martinez C \& Grupo GEAM. Análisis de situación y adecuación de dietas para disfagia en un hospital provincial. Nutr Hosp 2006; 21:26-31.

25. Wright L, Cotter D, Hickson M \& Frost G. Comparison of energy and protein intakes of older people consuming a texture modified diet with a normal hospital diet. J Hum Nutr Dietet 2005; 18:213-9.

26. Hamilton K, Spalding D, Steeleand C \& Waldron $\mathrm{S}$. An audit of nutritional care delivered to elderly inpatients in community hospitals. J Hum Nutr Dietet $2002 \cdot 15 \cdot 49-58$

27. Nowson CA Sherwin AJ, McPhee JG, Wark JD \& Flicker L. Energy, protein, calcium, vitamin D and fibre intakes from meals in residential care establishments in Australia. Asia Pac J Clin Nutr 2003; 12:172-7.

28. Kondrup J, Johansen N, Plum LM, Bak L, Larsen IH, Martinsen A, Andersen JR, Baernthsen H, Bunch E \& Lauesen N. Incidence of nutritional risk and causes of inadequate nutritional care in hospitals. Clin Nutr 2002; 21:461-8.

29. Giménez PJ, Satorra TB, Orrio CN \& Santamaría AL. Influencia de la textura de la dieta sobre el estado nutricional en adultos mayors. Gerokomos 2009; 20:105-8.

30. Powers $\mathrm{CH}$, Hess MA \& Kimbrough M. How 
Accurate Are Your Nutrient Calculations? Why Culinary Expertise Makes a Difference. J Am Diet Assoc 2008; 108:1420-2.

31. Rolls BJ, Roe LS \& Meengs JS. Larger Portion Sizes Lead to a Sustained Increase in Energy Intake Over 2 Days Am Diet Assoc 2006; 106.543-9.

32. Rolls BJ, Ree LS, Meengs JS \& Wall DE. Increasing the portion size of a sandwich increases energy intake. J Am Diet Assoc 2004; 104:367-72.

33. Porrini M, Santangelo A, Crovetti R, Riso P, Testolin $\mathrm{G} \&$ Blundell JE. Weight, protein, fat and timing of preloads affect food intake. Physiol Behav 1997; 62:563-70.

34. Bell EA \& Rolls BJ. Energy density of foods affects energy intake across multiple levels of fat content in lean and obese women. Am J Clin Nutr 2001;

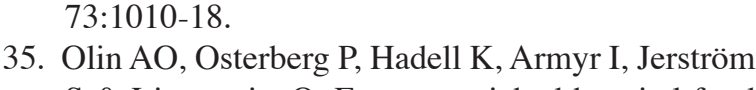
$\mathrm{s}$ \& L Lungqvist O. Energy-enriched hospital fod to improve energy intake in elderly patients. JPEN 1996; 20:93-7.

36. Johnson RM, Smiciklas-Wright H, Soucy IM \& Rizzo JA. Nutrient intake of nursing-home residents receiving pureed foods or a regular diet. J Am Geriatr Soc 1995; 43:344-8.

37. Barton AD, Beigg CL, Macdonald IA \& Allison SP. A recipe for improving food intakes in elderly hospitalized patients. Clin Nutr 2000; 19:4510-40.

38. Gall MJ, Grimble GK, Reeve NJ \& Thomas SJ. Effect of providing fortified meals and between-meal snacks on energy and protein intake of hospital patients. Clin Nutr 1998; 17:259-64. 